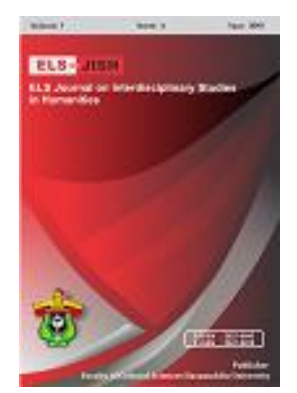

\title{
ELS-JISH
}

ELS Journal on Interdisciplinary Studies on Humanities

Volume 2 Issue 2, 2019

ISSN (print) : 2621-0843

ISSN (online) : 2621-0835

Homepage : http://journal.unhas.ac.id/index.php/jish

\section{Demotivational Factors of Non-English Major Students in Learning English}

\author{
Widya Rizky Pratiwi ${ }^{1}$
}

whywied.engvio88@gmail.com

\begin{abstract}
The low score obtained by the students is one of the factors, which scale down non-English major students 'motivation in learning English, and vise versa. This case results the students seem to be indifferent to this important lesson. Demotivation is discussed due to its negative orientation and it has direct educational implications. Thus, it seems necessary to investigate and explore demotivational factors in learning English of non-English major students in order to improve the quality of education in Indonesia. The subject of this qualitative case study was learners of information system and computer department in STMIK Bina Adinata, South Sulawesi, Indonesia. A total of 51 students responded to the questionnaire which analyzing 30 items of six demotivational constructs use Guttman scale format and 6 students of the third semester in academic year 2018/ 2019 who got the lowest scores in the last semester represented in-depth interviews to dig deeper their perception about demotivational factors they perceived during learning English at college. The results show that lecturers' inappropriate teaching method, inadequate facilities, grammatically teaching material, lack of students' selfconfidence, low score, little chance to practice and lack of students' awareness were the most demotivating factors for non-English major students. This information then can be used as a basic goal setting, method, strategy, and relevant learning materials with the needs of graduates. However, the lecturer is the most important key who can restore students' motivation in English language learning.
\end{abstract}

Keywords: Low Score, Negative Orientation, Motivation, Information System And Computer Department

How to cite: Pratiwi, W.R. (2019). Demotivational Factors of Non-English Major Students in Learning English. ELS Journal on Interdisciplinary Studies in Humanities, 2 (2), 193-205.

\section{Introduction}

Since mastery of English is one of the conditions to deal with demands of globalization, it has been one of necessity for the human being. English is the tools for world information exchange because almost all references of reading about science, the guidance of using technology and global information in the worldwide webs are written in English. Thus, Jin (2014) informs that learning and mastering English as a foreign language becomes the basic requirement for the citizens of each country in this $21^{\text {st }}$ century.

${ }^{1,}$ STMIK Bina Adinata, Indonesia 
Many governments around the world have implemented some efforts to introduce English early to young students and in recent years, according to Quadir (2011), English teaching in most Asian countries has been focused to the communicative language to make English education more relevant to students' necessities. In Indonesia, English has been introduced for many years at school and in its development, English is taught in a very basic level of formal education as a compulsory subject. However, (Rabia, 2015) the role is still as a foreign language and the outcome still has not satisfied because very few of graduating students are able to communicate well.

Honestly, students can deeply understand some advantages of being good at English. But they may find some problems in the process of learning. Demotivation and the causal factors are like the spinning wheels. Sometimes demotivation can be causative (i.e. have an effect on learning) and it can be resultative (i.e. be influenced by learning). Unsatisfied expectation such as the low score obtained by the students as a result of study during one semester may become one of the factors causing demotivated students to learn English. And vice versa, students who feel demotivated become lazy to learn and this can lead to the low score gotten by the students. Not only that, when students lose their interest in learning, some negative attitudes emerge such like they do not prepare for the class including doing homework, sleeping at class, talking to each other, giving negative comments, and using cell-phones at class. They seem to be indifferent to this important lesson.

The phenomena are mostly found in non-English major students. English, particularly included in almost every schools and universities, even though nonEnglish major colleges. When working with non-English major students who concentrate on studying computer and information system, I sometimes find some students who do not give their whole attention to the class when learning English. In addition, there are also indications that the quality of students English proficiency is still low. Most of the lecturers' expression and instruction by using the most basic English is difficult for students to be understood if the instruction is not translated into the first language. The lack of concentration and low English proficiency at English class seems to interpret that the students do not get enough motivation to aware the important role of English for them in supporting their own major. However, they really know English will be very beneficial in their life. Unfortunately, Le Nguyen (2015) identifies the interest of students who are not majoring in English is not the same as how well they view the important role of this subject in which students seem unwilling and reluctantly to learn English as a compulsory discipline in their colleges. It is also supported by Jin's statement (2014, p.253) who says "most of the college learn English as a compulsory course, so many of them show low motivation in English study and even completely give up learning English".

Just as motivation is important, demotivation is also the significant issue in SLA research and language learning (Sugino, 2010). In order to improve the quality of education, it is deeply important to worth investigating demotivational factors which hamper the success of English language learning at non-English major students. Afrough, Rahimi \& Zarafshan (2014); Kim \& Kim (2015) indicate however most of SLA research has explored students' motivation, nevertheless only a few studies concern about students' demotivation and this is a new area of investigation. 


\section{Method}

This research study applied a qualitative design of case study. Denzin and Lincoln (2011) note qualitative research studies the objects in the natural environment, trying to understand or interpret phenomena in the viewpoint of the meaning given by society to them. While the case study is design of inquiry found in many fields, especially evaluation, in which the researcher develops an in-depth analysis of a case, often a program, event, activity, process, or one or more individuals for one period or across multiple periods of time (Creswell, 2014; Neuman, 2014). By conducting this research method, the researcher described, interpreted and explored demotivational factors that cause the low score and lack of quality of English comprehension skill of information system and computer students as non-English majors.

The researcher used the concept of purposeful sampling to choose the individuals and the site for studying. Purposive sampling is a technique of selecting data sources sample with certain considerations (Sugiyono, 2016:300). The participants consisted of 51 students of the third semester in academic year 2018/2019 from both information system and computer major in STMIK Bina Adinata who enrolled in English class. The classes were chosen based on preliminary observation in which found most students with the low score of English in previous semester were obtained by the students in this grade, although the overall students at STMIK Bina Adinata do not have enough skill yet in English.

During the process of the research, the researcher studied the case by distributing questionnaires and followed up by interview. The data were collected and gained through participants' first language. Using questionnaires is being economical, practical, and bring longitudinal information from learners in a short period. The essential questionnaires relevant to demotivational factors in English language learning (ELL) were designed. The questionnaires consisted of 30 items which divided into 6 typical items; (i) Lack of adequate Learning Contents and Materials, (ii) Lecturers' inadequate Competence and Teaching Methods, (iii) Inadequate Facilities, (iv) Lack of Intrinsic Motivation, (v) Test Score, (vi) Unfavorable classroom climate and opportunities (adapted from Sakai \& Kikuchi, 2009; Afrough, Rahimi, \& Zarafshan (2014). Guttman scale was administered in this questionnaires in which the participants were required to choose one of two alternatives of assertive response "agree" or "disagree". The interview was also helped the researcher to follow up the result of questionnaires and to get the apt responses from the data collection. The type of interview conducted in this research was an in-depth - face to face interview. The interview was only addressed to 6 participants who got the lowest score in English. The researcher was dealing directly with participants to ask students' perception of English lesson, the most influential factor for students' demotivation in English Language Learning, mentioning other demotivating factors which were not referred in the questionnaire, students' suggestions to improve the quality of Teaching English as Foreign Language to lead us find out solutions from the problems occurred. Actually, all the respondents answered all the questions asked in the interview the but because of limited space, only salient and insightful responses were reported or they were reported in the form of the conclusions of all responses. 
Miles \& Huberman (1994 as cited in Sugiyono, 2016) argued that activity in qualitative data analysis is done interactively and continuously to complete, so the data is saturated. After collecting the data, there are three activities in the analysis of the data; (1) data reduction, data display, and conclusion drawing/ verification. The data of questionnaires were calculated with the assistance of Microsoft Excel. Then, the results were not presented in form of numerals. Nevertheless, they were described by interpreting the meaning of students' response percentage. The data of interview would be noted, recorded and transcribed. After the researcher read and looked all the whole data have been noted and transcribed, both questionnaire and interview's results were coded, and the researcher used the coding process to interrelate between theme and subtheme, advanced how the themes and subtheme would be represented in the qualitative research study, and a final step in data analysis involved making an interpretation and finding out the solutions as the result of case studies about demotivational factors of non-English major students in English language learning, then taking a conclusion of what the lessons have been learned by conducting this research study

\section{Finding and Discussion}

Based on questioners' distribution to 51 students as participants, it was found that in fact students of STMIK Bina Adinata are not included in the level of very low motivation in learning English. However, there are still several factors which affect their motivation decreased. It was shown that overall, no students respond "agree" more than $90 \%$ for each item of demotivational factors being asked. For more details, the data were described in the following table.

Note:

$$
\begin{aligned}
& { }^{* * * * *} \text { response (agree) from }>90 \% \text { of respondents. } \\
& { }^{* * * *} \text { response }(\text { agree) from }>75 \% \text { of respondents. } \\
& { }^{* * *} \text { response }(\text { agree) from }>50 \% \text { of respondents. } \\
& { }^{* *} \text { response }(\text { agree) from }>25 \% \text { of respondents } \\
& { }^{*} \text { response (agree) from }<25 \% \text { of respondents }
\end{aligned}
$$

\begin{tabular}{|c|c|c|}
\hline $\begin{array}{l}\text { Most of the lessons focuse } \\
\text { on the grammars and it is } \\
\text { boring. } \\
\text { * }\end{array}$ & $\begin{array}{l}\text { dThe topics taught was not } \\
\text { relevant } \\
\text { with the major of my } \\
\text { discipline. } \\
\text { * }\end{array}$ & $\begin{array}{l}\text { A great number of textbooks } \\
\text { and supplementary readers } \\
\text { were assigned } \\
\star *\end{array}$ \\
\hline $\begin{array}{l}\text { English sentences dealt } \\
\text { with in the lessons were } \\
\text { difficult to interpret. } \\
\star *\end{array}$ & $\begin{array}{l}\text { I was expected to use (or } \\
\text { speak and write) } \\
\text { grammatically correct English } \\
\star \star \star \star\end{array}$ & $\begin{array}{l}\text { Old topics and texts used in } \\
\text { the } \\
\text { Lessons } \\
* * *\end{array}$ \\
\hline
\end{tabular}

Table 1. Lack of adequate Learning Contents and Teaching Materials

For the first factor, six questions were asked and the majority of students felt disturbed by the lecturers' expectation of grammatically correct English. Beside that 
lecturer did not update the latest information to be used as the reference of teaching materials so students are less motivated.

Table 2. Lecturers' inadequate Competence, Attitude, and Teaching Methods

\begin{tabular}{lll}
\hline $\begin{array}{l}\text { Lecturers' explanations } \\
\text { were not }\end{array}$ & $\begin{array}{l}\text { Lecturers' pronunciation } \\
\text { of English was poor } \\
\text { easy to understand }\end{array}$ & $\begin{array}{l}\text { Lecturers made one-way } \\
\text { explanations too often } \\
*\end{array}$ \\
\hline $\begin{array}{l}\text { Lecturers ridiculed } \\
\text { students' mistake }\end{array}$ & $\begin{array}{l}\text { Lecturers shouted or got } \\
\text { angry. }\end{array}$ & $\begin{array}{l}\text { The pace of lessons was } \\
\text { not appropriate } \\
* *\end{array}$ \\
\hline Lecturers' uninteresting & Lecturers' inadequate & \\
teaching method & language abilities & \\
$*$ & $*$ & \\
\hline
\end{tabular}

The second factor above shows that from 8 items which asked about lecturer information, the most prominent students' response to the cause of students' demotivational factor was lecturers' explanations were not easy to be understood, then it was followed by an inappropriate pace of lessons.

Table 3. Inadequate Facilities

\begin{tabular}{ll}
$\begin{array}{l}\text { No or little use of } \\
\text { computers }\end{array}$ & $\begin{array}{l}\text { No or little use of visual aids No or little use of the internet } \\
\text { or audio devices such as } \\
\text { videos, } \\
\text { tape recorder and DVDs } \\
\star * \star *\end{array}$ \\
\hline $\begin{array}{l}\text { There is no language } \\
\text { laboratory }\end{array}$ & $\begin{array}{l}\text { Ignore or minimize the } \\
\text { function of library } \\
* * *\end{array}$ \\
\hline
\end{tabular}

Table 3 describes the information on campus facilities. There were 5 items being asked, and almost all the items become the cause of the students' low motivation to learn English mainly to the little use of computers and visual aids/ audio devices.

Table 4. Lack of Intrinsic Motivation

\begin{tabular}{ll}
\hline I lost my interest in & $\begin{array}{l}\text { I lost my understanding of English was only a } \\
\text { the purpose of studying }\end{array}$ \\
$\begin{array}{ll}\text { English } \\
\text { English }\end{array}$ & $*$ \\
\hline
\end{tabular}

Lack of self-confidence to speak English in classroom

** 
The above result represents that intrinsic motivation factors have little effect on students' motivation weakness in learning English

Table 5.Test Scores

\begin{tabular}{lll}
\hline I could not do as well on & I got low scores on tests & Doing speaking activities \\
tests as my friends & (such as mid-term and final & just for score, not to \\
& examinations). & communication \\
& $* * *$ & $* * *$ \\
\hline
\end{tabular}

From 3 items asked in table 5, the low test scores obtained by students seemed to greatly affect the decrease in motivation and made depress majority of participants in learning English. Students are likely to complete their assignment to get good grades rather than learning it for a lifetime.

Table 6. Unfavorable classroom climate and opportunities

\begin{tabular}{|c|c|c|}
\hline $\begin{array}{l}\text { Little chance of } \\
\text { communicating in English } \\
\text { inside the class }\end{array}$ & $\begin{array}{l}\text { Not doing speaking activities } \\
\text { because of short class time } \\
\star \star *\end{array}$ & $\begin{array}{l}\text { Little chance to } \\
\text { communicate in English } \\
\text { outside the class }\end{array}$ \\
\hline *** & & 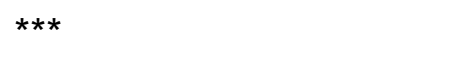 \\
\hline \multicolumn{3}{|l|}{$\begin{array}{l}\text { Feeling anxious while } \\
\text { speaking }\end{array}$} \\
\hline \multicolumn{3}{|l|}{$\begin{array}{l}\text { because of classmates' } \\
\text { laughter }\end{array}$} \\
\hline $\begin{array}{l}\text { and teacher's } \\
\text { inappropriate reactions }\end{array}$ & & \\
\hline & & \\
\hline
\end{tabular}

Factor 6 explains that a lot of class time, big chance of communicating in English inside and outside the class may increase students motivation in learning English and these efforts may change the mindset of some students in their motivation to learn English that was originally merely instrumental or practical purpose to be an integrative motivation for long-term learning objectives.

According to the result of questionnaire, overall it can be conclude that most of non-English major students (more than 75\%) are demotivating to learn English when lecturer expects them to use (or speak and write) grammatically correct English and little use of supporting technology such as computer and audio and visual aids.

In addition of concluding the questionnaire data, the results of data analysis on the interview record should be shown to know more about the demotivational factors causing students obtain an unsatisfactory score. Some extracts below represent each question posed during the interview session.

\subsection{English is Important}

English has a feature in which it is a world language and lingua franca. Ishikawa (2016) highlights that English has now become a communication medium for many Asian people. Based on the results of interviews conducted on some students with 
purposive sampling, all interviewees have similar opinions about the importance of English taught in their majors. One of the students' opinion can be seen in the following extract:

R: What do you think about English lesson?

$\mathrm{S}_{3}$ : English is very important. It is very helpful in the mastery of skills in our field of study, computer. As we know all the contents of computer programs use English in the instructions.

The extract above explains that in addition to its essence as an International language, English plays an important role in supporting the improvement of competence in their field of study. Not for the information system and computer department only, all areas of study taught in the first language require English skills to be able to disseminate such knowledge in the global world.

However, although they realize the importance of English, there were still many students who neglected this important lesson and it resulted in the low test scores and inadequate English competence qualities of the students. Some students also said that English is important but they added with contrary explanations behind their previous sentence e.g students' disinterest in English and inability to absorb this lesson. The examples of students' responses can be seen in conversations below:

R: What do you think about English lesson?

$S_{5}$ : I am well aware that English is very important, but eeeeemm somehow I am not interested to know more about English.

$S_{6}$ : I really need enough knowledge in English because it can help us who work in the field of ICT and we can communicate using English with our business partner, but English is very difficult and I do not know when should start to get better.

This extract explains that students actually have the motivation to learn English but they seem to find various obstacles that make their motivation decreased. Therefore, a deep investigation of the reasons why they are not interested or difficult to learn English is needed.

\subsection{The Most Influential Factors of Students' Demotivation in Learning English}

To continue a deeper investigation, the researcher turned to the next question related to the questionnaire that has been filled before. It was about the most influential factors of students' demotivation in learning English. All interviewees provided different answers according to what they felt. The quotations below are the students' responses to the question given.

Q: From the six factors that have been discussed on questionnaire filling, what factors are most influential on the decreased of your motivation to learn English?

$\mathrm{S}_{1}$ : Inadequate facilities make students less eager to learn English. The lack of internet and audiovisual use makes the teaching process seems rigid because it relies on textbooks only. 
$S_{2}$ : Lecturer is the most influential factor. If the lecturers are creative, competent and fun, the students will be interested and motivated to learn English even if only with plain facilities. But if the lecturers are boring, the material taught also feels boring, and it automatically makes students do various negative activities in the class like playing mobile phone, talking to each other, noisy, and so on.

$S_{3}$ : I have never trusted myself that I am able to master English especially when I know I get the low score in English and it makes me frustrated. Besides, lack of time to learn English at class cause application of given materials is also less.

$\mathrm{S}_{4}$ : Lecturer, material, and time to practice. By using a textbook, lecturers sometimes forget that English requires practice conversation in front of the class because this activity trains English skills as well as train selfconfidence. Lecturers sometimes practice pronunciation in accordance with the text in the textbook but that is not enough.

$\mathrm{S}_{5}$ : I am lack of self-confidence, besides my lecturers explain the material too quickly and seriously, too many memorizing tasks and lecturers teach grammar too often like simple present tense that we do not really need.

This makes me not interested to know more about English and lazy to follow the process of learning in the classroom. I attend the class just to pass the lesson because even though I do not interest, I have to keep following the lesson as a compulsory subject that must be followed.

$S_{6}$ : I am not confident and feeling anxious when making wrong pronunciation in front of friends. I am afraid of being laughed at by friends. I still find it is difficult to pronounce words correctly in English because the writing and pronunciation are different.

The quotations above show there are various factors that cause students demotivated in English language learning. They vent their different feelings as they have experienced. Some of their answers support data from questioner's results that have been done before by the entire third-semester students of information system and computer department in STMIK Bina Adinata.

Student 1 required adequate facilities in the learning process, thus lecturers can transfer and distribute the material with various methods in each meeting such as watching videos, listening to music, the material is displayed in the form of pictures, etc so that the material is not only fixated on textbooks that make students feel bored and sleepy at class. The perception of this student 1 supports the results of the thirdfactor questioner "inadequate facilities" which most of the students expressed the need for use technology in the classroom.

Student 2 stated that lecturers become a very influential factor in students' motivation in the learning process. Students need lecturers who are competent and creative so the lessons that are considered difficult by some of the people become more interesting and feel easier. Overall, most of the students like lecturers' attitude but some of them have problems with the lecturers' competence and teaching methods. The results of the questionnaire on the item number 7 "students are demoted because lecturers' explanations were not easy to understand " also 
explained that lecturers' competence is very important. However, the results of the questionnaire indicate that the lecturer is not very influential in determining students' motivation to learn English. Demotivational experiences related to the lecturers may only be perceived by students in small numbers.

After exploring students 4 , it was found that there was a close relationship between lecturers, materials, and opportunities to apply the use of English language inside or outside the classroom (it can also be found in the questionnaire item no $1,3,13,27,28$ and 29). A great number of textbooks used and focused more on grammar leads to a lack of intensity of conversation exercises related to their field. Course content in most of the universities in Indonesia which focus on grammar highly discourage the students and it makes students find themselves lost in this way. Yadav (2014) informs the results make it clear that the English used in textbooks, is too hard for the student and hence a strong demotivator.

According to the data found in the field, it was identified that the demotivation factor is not only derived from external factors, but also from internal factors. Students 3, 5 and 6 revealed that one of the factors that make them unmotivated to learn English because they lack confidence so there is no encouragement to grow. It seems they do not trust their own abilities. Not only that, there are several other external factors that are simultaneously perceived as demotivators by each of the students. Student 3 said the low score she got and lack of time to learn English make her more frustrated. Actually, one of the Indonesian government's efforts to advance the education in Indonesia is by placing English lesson as one of the curriculum at high schools and colleges. But unfortunately, it is usually taught only 2 credits for one semester in most of non-English majors such as information system and computer department. English learning time is relatively less proportional to the needs of students, thus the frequency of learning in colleges is also less support for improving the quality of English learning (Hermayawati, 2010). Student 5 considered lecturers who do not match the expectations would be the start of her failure to love English. While student 6 need motivation from lecturers or people around to encourage her to grow self-esteem, self-confidence and eliminate anxiety in speaking English in public place because this type of student only has intrinsic motivation problems.

\subsection{The Other Demotivational Factors of Information System and Computer Students}

In order to find out other demotivational factors in non-English major students that may be slightly different from previous studies, researcher continued to the next question "do you find the other factors that become demotivators in learning English apart from the 30 items that have been mentioned in the questionnaire?".

This question invited various positive reactions from interviewees to expose more what they feel which is not suitable with their expectations that results to the low motivation, low test score, frustration and leads to failure. Of course, to achieve educational goals, all levels of educational practitioners such as students, teachers, lecturers, and stakeholders do not want to fail. Because the failure in education will make Indonesia more left behind other countries.

Students are enthusiastic in delivering their complaints to find out solutions related to demotivation factors they experienced. Basically there are still many factors that make the motivation to learn English decreased, among others (1) 
unclear textbooks or lecturers' instructions makes some students do not understand and they sometimes do not submit the tasks assigned; (2) the time allocation to learn English in information system and computer department is less, there are only 2 credits in a week so students also have little time to discuss the lessons and train their conversations; (3) inadequate brain capacity because learning another language requires students to memorize many vocabularies; (4) students do not have enough knowledge even though they have learned English since high school. This case is caused by several factors such as teachers who rarely teach, students have never taken English courses or join English community; (5) There are students who sometimes feel offended to be treated like high school students, lecturers questioning assignments, demanding students neatly, politely and coming on time.

\subsection{The Methods to Increase Students' Motivation in Learning English}

Related to the problems that become the factors causing the decrease of students' motivation in learning English found in non-English major students especially in information system and computer department, hence this research study needs to find out solutions to the related problems.

Based on the results of in-depth interviews to 6 students, it is known that some of their motivations have increased because there are some improvements in teaching quality and this may be as one of the evaluation function conducted by quality assurance institutions in universities. Here is a conversation transcript conducted by the researcher with one of the respondent.

Q: How is the condition of the English teaching process that you feel right now?

$\mathrm{S}_{2}$ : In the first and second semester, I felt the level of my motivation to learn English was very weak, but in this semester I am experiencing little progress that improves my motivation such as submitting tasks through Whats Up group (WA). Our lecturer said, "it would be better if your leisure time is used to memorize vocabularies rather than wasting your time". Some vocabularies which have been memorized can be recorded and submitted through WA group so lecturer and friends can see our performance and progress.

As we know that mobile learning (m-learning) such as the using of whats up (WA) is a new trend in developing technology. The extract above shows that the lecturers begin to utilize the mobile learning system in which students and lecturers can do the learning process anytime without having to meet face to face. Students have also more opportunities to ask materials have not been understood yet through this groups. This way is very effective to stimulate students to be more interested in learning English. The explanation is also supported by Ozdamli \& Cavus' statement (2011). They reveal m-learning is a kind of learning model allowing learners to obtain learning materials wherever and whenever they are using mobile technologies and the Internet in which learner, teacher, environment, content and assessment are basic elements of the complete mobile learning. They then explain the core characteristics of mobile learning are ubiquitous, portable size of mobile tools, blended, private, interactive, collaborative, and instant information that enable learners to be in the right place at the right time, that is, to be where they are able to experience the authentic joy of learning. 
Besides, the information was also obtained that the positive thing which students felt in this semester is a second chance to do the task. As described above the lack of clarity of instructions on textbooks and what the lecturers say, makes students sometimes do not understand the tasks assigned. But at the next meeting, students who did not submit the assignment are directed and accompanied in completing their task. This explanation is evidenced by the quotation below

$S_{3}$ : The low score made me feeling more indifferent and lazy to finish the task especially if the material is rather boring. But in the next meeting, the lecturer keeps giving direction and second chance to do the task.

Assessment is very important in the learning and instructional process. The result of student achievement score is the basis for assessing the teacher's instructional competence or effectiveness as teacher's evaluation (Joshua, Joshua \& Maliki, 2007). Therefore the low score obtained by students is also a symbol lecturer's failure in teaching. Thus, to improve the quality of both lecturers and students, lecturers should give second chance to the students who have not understood the instruction of the given task.

In addition to the above extracts, there are some students' expectations that may become the solutions to the problem of demotivation factors in English language learning. The following are:

1. In the early semester before starting the lesson, the lecturers have to explore the students' needs and interests of this lesson.

2. In each meeting, the lecturers are expected to tell about the experience of some successful people if mastering English on the sidelines of giving material. It will stimulate and motivate students to study hard

3. In explaining or giving instruction, the lecturers are hoped to use target language but followed by the first language.

4. Conversation practices related to the field of study will be more motivating rather than focused on grammar

5. Lecturers should give clear instructions when giving the tasks

6. Time allocation of learning English at class needs to be added

7. Establishing a kind of English community as an extra activity on campus

\section{Conclusion}

A demotivated learner is someone who has lost his/ her interest to study for some reasons. His/ her loss of interest can be sourced from different factors both internal and external. Demotivation contains negative orientation and it has direct educational implications because it limits the students' performance.

The purpose of this study was to find out the factors which pull down nonEnglish major students' motivation in English language learning. These demotivating factors certainly lead the students to unsatisfactory learning outcomes, frustrations, and failures in which need immediately to be solved. Not only motivation, the discussion of demotivation also needs to be studied more deeply as an evaluation material to the ongoing teaching process. The information then can be used as a 
basic goal setting, method, strategy, and relevant learning materials with the needs of graduates in order to improve the quality of education in Indonesia.

The results of this qualitative case study showed learners realize the importance of English in supporting the improvement of competence in their field of study of both information system and computer department. However, they found various obstacles that make their motivation decreased in the learning process.

From 6 factors consisted of 30 items presented, some of the most demotivators for non-English major students were lecturers' inappropriate teaching method, inadequate facilities, grammatically teaching material, lack of students' selfconfidence, low score, little chance to practice. In addition, from the results of indepth interviews were also found other demotivational factor, which derived from the students themselves namely lack of students' awareness. The items were limited capacity of students, insufficient basic knowledge of students, discrepancy of students' character and principle with the educational goals.

Concerning the demotivating factors will never escape the discussion of motivation because motivation arises before demotivation. Lecturer is the most important key who can restore students' motivation in English language learning which has been decreased or lost. Lecturer is able to change appropriate teaching methods, improve teaching materials according to the students' need and interest, is able to consider the students' score, utilize the facilities as well as possible, provide more opportunities to practice speaking as forming English community, and lecturer is able to give advice to students who lack of self-confidence and awareness. However, these efforts require the cooperation of all related ones.

\section{Acknowledgement}

This research was supported by the head, all lecturers, staffs, and students of STMIK Bina Adinata. Thank you very much for all kinds of help to finish this research study.

\section{References}

Afrough, T., Rahimi, A., \& Zarafshan, M. (2014). Foreign Language Learning Demotivation: A Construct Validation Study. Procedia-Social and Behavioral Sciences, 136, 49-53.

Creswell, J. W. (2014). Research Design: Qualitative, Quantitative, And Mixed Methods Approaches. Sage Publications Hermayawati. (2010). Analisis Kesulitasn Belajar Bahasa Inggris Mahasiswa. Jurnal Sosio-Humaniora, 1 (1), $1-14$.

Denzin, N.K., \& Lincoln, Y.S. (2011). Introduction: The discipline and practice of qualitative research. The Sagebook of qualitative research (4th ed, p. 1-19). Thousand Oaks, CA: Sage.

Ishikawa, T. (2016). World Englishes and English as a Lingua Franca: conceptualising the legitimacy of Asian people's English. Asian Englishes, 18(2), 129-140.

Jin, M. (2014). A Case Study of Non-English Major College' Motivation in English Language Learning. Open Journal of Modern Linguistics, 4(02), 252. 
Joshua, M. T., Joshua, A. M., \& Maliki, A. E. (2007). Use of student achievement scores as basis for assessing teachers' instructional effectiveness: Issues and research results. J. Hum. Ecol, 22(2), 135-140.

Kim, T. Y., \& Kim, Y. K. (2015). Elderly Korean learners' participation in English learning through lifelong education: Focusing on motivation and demotivation. Educational Gerontology, 41(2), 120-135.

Le Nguyen, N. T. (2015). How to motivate non-English major students in Vietnamese universities of education to learn English. TESOLConference (Pp. 1-12). Retrieved

from http://www.vnseameo.org/TESOLConference2015/Materials/Fullpaper/Ms.\%20 Nguyen\%20Thi\%20Le\%20Nguyen.pdf

Neuman, L. W. (2014). Social research methods: Qualitative and quantitative approaches (7th ed). USA: Pearson Education Limited

Ozdamli, F., \& Cavus, N. (2011). Basic elements and characteristics of mobile learning. Procedia-Social and Behavioral Sciences, 28, 937-942.

Quadir, M. (2011). A Comparative Study of English and Non-English Major University ' Motivation to Learn English Oral Communication. Journal, 2, 91-111.

Rabia, S. (2015). The Students Learning Strategies in Speaking at Genta CoursePare Kediri. (Masters thesis, Fakultas Tarbiyah dan Keguruan, IAIN Antasari Banjarmasin, Indonesia). Retrieved from http://idr.iainantasari.ac.id/393/

Sakai , H., \& Kikuchi, k. (2009). An analysis of demotivators in the EFL classroom. System. 37, 57-69

Sugino, T. (2010). Teacher demotivational factors in the Japanese language teaching context. Procedia-social and behavioral sciences, 3, 216-226.

Sugiyono.(2016). Metode Penelitian Pendidikan: Pendekatan Kuantitatif, Kualitatif, Dan $R \& D$. Bandung: Alfabeta.

Yadav, M., \& BaniAta, H. (2013). Factorizing demotivation, finding motivation: A constructive approach to quality enhancement. Procedia-Social and Behavioral Sciences, 70, 120-130 